\title{
Odrodzenie i kształtowanie się ruchu anarchistycznego w Polsce od lat osiemdziesiątych XX w.
}

\begin{abstract}
Abstrakt: Artykuł przedstawia historię ruchu anarchistycznego w Polsce od lat osiemdziesiątych XX w. Pierwszą grupą anarchistyczną w Polsce po II wojnie światowej był Ruch Społeczeństwa Alternatywnego, który powstał w 1983 r. W 1989 r. została utworzona Federacja Anarchistyczna. Najważniejsze czasopisma anarchistyczne w tym okresie to: „Mać Pariadka”, „Inny Świat” i „Przegląd Anarchistyczny”. W polskiej myśli anarchistycznej dominowały anarchokomunizm i anarchosyndykalizm.
\end{abstract}

Słowa kluczowe: anarchizm, transformacja polityczna, myśl polityczna, ruchy społeczne, władza, państwo, wolność.

Abstract: The article presents the history of the anarchist movement in Poland since the 1980s. The first anarchist group formed in Poland after World War II was the Alternative Society Movement, established in 1983. In 1989, the Anarchist Federation was founded. The most important anarchists periodicals were: Mać Pariadka, Inny Świat (Another World), and Przeglad Anarchistyczny (Anarchist Review). The Polish anarchist thought was dominated by anarcho-communism and anarcho-syndicalism.

Key w ords: anarchism, political transformation, political thought, social movements, power, state, freedom.

Anarchizm to myśl polityczna, w której idea przewodnią jest wolność interpretowana zarówno w znaczeniu pozytywnym, jako „wolność do”, jak i negatywnym, jako „wolność od”. Istotę anarchizmu stanowi uznanie całkowitej i nieskrępowanej prawem wolności pojedynczego człowieka i dobrowolnie 
organizujących się grup ludzkich złożonych z jednostek niezwiązanych przymusem $^{1}$. Z anarchistycznej krytyki hierarchicznych organizacji, w tym państwa, wynika wizja wolnego, samorządnego i sprawiedliwego społeczeństwa, która może być interpretowana jako utopijna i nieziszczalna, co bynajmniej nie znaczy, że jest absurdalna ${ }^{2}$. Anarchistyczna krytyka państwa, demokracji, instytucji hierarchicznych, a współcześnie także procesów globalizacyjnych, może bowiem przybrać postać destrukcyjną wobec społeczeństwa wówczas, kiedy jest realizowana, ale może być funkcjonalna wobec niego, kiedy jest nierealizowana, ale wskazuje istotne zakłócenia w funkcjonowaniu państwa, systemu politycznego, gospodarki, elit społecznych czy instytucji.

Ruch anarchistyczny w Europie kształtował się od drugiej połowy XIX w. Z tego okresu pochodzą dzieła anarchistów, do których odwołują się ich współcześni akolici. Anarchizm to jednak nie tylko wizja wolnego społeczeństwa, oparta na idei sprawiedliwości i równości, ale także aktywność organizacyjna i propagandowa na poziomie międzynarodowym, jak również działalność terrorystyczna. Przełom XIX i XX w. przeszedł do historii jako czas terroryzmu motywowanego anarchizmem ${ }^{3}$.

$\mathrm{Na}$ ziemiach polskich anarchizm przełomu XIX i XX w. rozwijał się w postaci spontanicznie powstających, często efemerycznych grup, a także aktywności prekursorów polskiego anarchizmu. Idee anarchistyczne propagowali m.in. wybitny biochemik Augustyn Wróblewski (1866 - ok. 1913) ${ }^{4}$ i lekarz Józef Zieliński (1861-1927) ${ }^{5}$. Źródeł polskiej myśli anarchistycznej współcześni jej akolici poszukiwali w dziełach i aktywności pisarza i działacza politycznego Jana Wacława Machajskiego (1866-1926) oraz myśliciela społecznego, socjologa i psychologa Edwarda Abramowskiego (1868-1918), a także w aktywności anarchistów w czasie rewolucji lat 1905-1907 w Rosji i Królestwie Polskim, przedwojennych strukturach organizacyjnych, jak np. Anarchistycznej Federacji Polski (AFP), która działała w latach dwudziestych i trzydziestych XX w., czy w powstałym w 1939 r. Związku Syndykalistów Polskich (ZSP). Wzorami aktywizmu motywowanego ideami anarchistycznymi były dla nich takie postaci, jak Tomasz Pilarski (1902-1977), którego życiorys mógłby posłużyć za kanwę filmu sensacyjnego, czy anarchiści aktywni

${ }^{1}$ L. Kulczycki, Anarchizm w obecnym ruchu społeczno-politycznym $w$ Rosji, Warszawa 1907, s. 4.

${ }^{2}$ J. Muszyński, Anarchizm. Rzecz o nieziszczalnej wolności, Warszawa 1982, s. 6.

${ }^{3}$ Zob. B.W. Tuchman, The Proud Tower. A Portrait of the World Before the War, London 1966; W. Potkański, Terroryzm na ustugach ugrupowań lewicowych $i$ anarchistycznych w Królestwie Polskim do 1914 roku, Warszawa 2014.

${ }^{4}$ Zob. A. Wróblewski, Anarchista z rozpaczy, wybór, wstęp, przypisy R. Antonów, Kraków 2011; A. Łaniewski, Augustyn Wróblewski: krakowski anarchista i „adwokat umartych”, „Studia z Dziejów Rosji i Europy Środkowo-Wschodniej” 2010, t. XLV, s. 277-297.

${ }^{5}$ Zob. A. Jeleń, Dr Józef Zieliński - polski anarchista $w$ Paryżu, w: Studia z dziejów polskiego anarchizmu, red. E. Krasucki, M. Przyborowski, R. Skrycki, Szczecin 2011, s. 174-187. 
w ramach ruchu oporu antyhitlerowskiego ${ }^{6}$. Dzieje polskiego anarchizmu tego okresu wieńczy koniec II wojny światowej i początek Polski Ludowej. Od tego czasu anarchizm jako ruch polityczny przestał istnieć, a nieliczne przykłady aktywności motywowanej anarchizmem, w formie towarzyskich spotkań i spontanicznych wystapień artystycznych oraz związanej z okresem kontestacji młodzieżowej lat sześćdziesiątych i siedemdziesiątych XX w., miały charakter epizodyczny i efemeryczny. Anarchizm odrodził się w latach osiemdziesiątych wraz z kształtowaniem się szerokiego i pluralistycznego ruchu opozycyjnego wobec państwa socjalistycznego.

Celem artykułu jest odtworzenie i usystematyzowanie procesu odradzania się ruchu anarchistycznego w Polsce od lat osiemdziesiatych XX w. oraz jego kształtowania się na przełomie XX i XXI w., ze szczególnym uwzględnieniem jego struktur organizacyjnych, działalności publicystycznej i propagandowej oraz innych inicjatyw i akcji społecznych. W artykule scharakteryzowane zostały także główne nurty myśli anarchistycznej oraz stanowiska anarchistów wobec wybranych wyzwań i problemów politycznych Polski, w tym przemian 1989 r. i wstapienia Polski do Unii Europejskiej, a także stosunek anarchistów do państwa, systemu politycznego i elit politycznych. Cele te autor osiagną poprzez analizę dokumentów i publikacji ruchu anarchistycznego z przełomu XX i XXI w. Ich wstępna analiza, a także wyniki badań naukowych w przedmiotowym zakresie ${ }^{7}$ posłużyły do sformułowania hipotezy, zgodnie z która anarchizm w Polsce w tym okresie odradzał się i kształtował w oparciu o maksymalistycznie interpretowaną ideę wolności, jako ruch pozostawał na marginesie form aktywności politycznej w Polsce, jednocześnie kwestionując kierunki przemian politycznych i gospodarczych w kraju.

\section{Odrodzenie anarchizmu w latach osiemdziesiątych XX w.}

Przełom lat siedemdziesiątych i osiemdziesiątych XX w. to czas, kiedy do Polski przenikały idee nowych subkultur młodzieżowych. Wśród nich była

${ }^{6}$ Zob. R. Chwedoruk, Ruchy i myśl polityczna syndykalizmu w Polsce, Warszawa 2011.

${ }^{7} \mathrm{Na}$ temat historii anarchizmu na ziemiach polskich zob. W. Kołodziej, Anarchizm i anarchiści $w$ Rosji i Królestwie Polskim, Torun 1992; Anarchizm i anarchiści na ziemiach polskich do 1914 roku, zebrał i oprac. H. Rappaport, Warszawa 1981; A. Łaniewski, Wizerunek anarchistów i anarchii na tamach „Naprzodu” $i$ „Robotnika” (1892-1927), „Dzieje Najnowsze” 2014, nr 4; W. Potkański, Działalność ruchów anarchistycznych w Królestwie Polskim na przełomie XIX i XX stulecia, „Bezpieczeństwo. Teoria i Praktyka” 2014, nr 4, s. 99-113; D. Wierzchoś, Polscy anarchiści podczas rewolucji i wojny domowej w Rosji (1917-1920), w: Studia z dziejów anarchizmu (2). W dwusetlecie urodzin Michaiła Bakunina, red. R. Skrycki, Szczecin 2016, s. 225-245. Anarchizm w Polsce przełomu XX i XXI w. był przedmiotem takich opracowań zwartych, jak m.in.: R. Antonów, Pod czarnym sztandarem. Anarchizm $w$ Polsce po 1980 roku, Wrocław 2004; P. Malendowicz, Polski ruch anarchistyczny wobec wspótczesnych wyzwań politycznych, Piła 2007. 
subkultura punk. Treści utworów muzycznych i prasy trzeciego obiegu (ziny, fanziny) związanej z tym ruchem akcentowały problematykę kontestacji systemu politycznego i anarchiczność jako alternatywę dla państwa ${ }^{8}$. Subkulturowość idei anarchistycznych stanowiła jednak tylko podłoże zainteresowania młodzieży tym nurtem myśli politycznej. To samo dotyczy innych subkultur, w tym np. hipisów.

Anarchizm jako ruch społeczny kształtował się jednakże niezależnie od subkulturowych konotacji anarchizmu. W 1983 r. w Trójmieście powstał Ruch Społeczeństwa Alternatywnego (RSA). W czasopiśmie „Homek”, które ruch ten wydawał w Gdańsku, jego założyciele oświadczyli, że domagają się amnestii, rozbrojenia, zniesienia kary śmierci i obowiązkowej służby wojskowej. Byli przeciwko władzy i państwu. Wolność uznali za wartość najwyższa. Postulowali budowę społeczeństwa alternatywnego, czyli „niezależnie myślących wspólnot, działających poprzez tworzenie klubów dyskusyjnych, niezależne wydawnictwa i ośrodki twórcze (kulturalne i naukowe), aż po niezależna działalność gospodarczą. Wszystko to poza policyjnymi strukturami państwa"9. To oznaczało utożsamianie się członków RSA z anarchizmem.

Poza aktywnością wydawniczą w ramach alternatywnego obiegu prasy RSA organizował spotkania klubu dyskusyjnego, a także inicjował manifestacje i happeningi. Istotną inicjatywą było utworzenie Porozumienia Grup Niezależnych „Wolność” w 1984 r. Należały do niego trójmiejskie organizacje młodzieżowe ${ }^{10}$.

Od końca lat osiemdziesiątych nieliczne i kilkuosobowe grupy RSA powstawały w innych regionach Polski, m.in. w Warszawie, Sochaczewie, Chełmnie, Białymstoku, Zakopanem, Szczecinie, Poznaniu, Łodzi, Słupsku, Lublinie, Krakowie i Rzeszowie. Grupy w tych miastach działały pod różnymi nazwami ${ }^{11}$.

Proces restytucji anarchizmu w Polsce wiązał się także z powstałą w 1985 r. nieformalna organizacją Ruch „Wolność i Pokój” (WiP). Uczestnicy WiP byli pacyfistami, ale współtworzyli ją także anarchiści. W deklaracjach ruch ten zwracał uwagę na zagrożenie wojną (także atomowa), prawa człowieka, wyzwolenie narodowe i potrzebę ochrony środowiska ${ }^{12}$.

Podobne znaczenie dla kształtowania się anarchizmu miało powstanie we Wrocławiu Pomarańczowej Alternatywy, której działalność objęła przede wszystkim aktywność happeningową o największym natężeniu w latach 1986-1989. Nazywana ona była „najbardziej kolorowym przejawem polskiej opozycji antykomunistycznej”. Jej symbolem stał się krasnoludek, a to za sprawą graffiti krasnali malowanych przez jej lidera w czasie stanu wojennego

\footnotetext{
${ }^{8}$ Por. J. Donaghey, Punk and Anarchism. UK, Poland, Indonesia, Loughborough 2016, s. 70-90.

${ }_{9}$ Ruch Społeczeństwa Alternatywnego, „Homek” 1983, nr 2, s. 1.

10 J.P. Waluszko, Ruch Społeczeństwa Alternatywnego, Sopot 1992, s. 5.

11 Ibidem, s. 1-14.

${ }^{12}$ Ruch Wolność i Pokój, Deklaracja ideowa, „A Ceppella” 1987, nr 3, s. 7-8.
} 
na plamach powstałych wskutek zamalowywania antykomunistycznych napisów na murach miast przez służby bezpieczeństwa. Działała ona także poza Wrocławiem, m.in. w Warszawie, Poznaniu, Krakowie i Łodzi. Istotne znaczenie dla oblicza i aktywności Pomarańczowej Alternatywy miała postać jej charyzmatycznego lidera Waldemara Fydrycha, zwanego „Majorem”, a następnie „Komendantem Twierdzy Wrocław”. W Pomarańczowej Alternatywie działali młodzi ludzie, którzy po latach tworzyli elity artystyczne kraju, a już w XXI w. również elity polityczne ${ }^{13}$.

W tym okresie ruch anarchistyczny nie funkcjonował $\mathrm{w}$ formie skrystalizowanej. Tworzony był przez RSA, który można określić mianem protagonisty anarchizmu kolejnej dekady, a także grupy „anarchizujace”, choć nie anarchistyczne, jak WiP czy Pomarańczowa Alternatywa.

W 1988 r. RSA, anarchiści z WiP oraz formacja artystyczna Totart powołali Międzymiastówkę Anarchistyczna ${ }^{14}$. Należało do niej stworzenie warunków służących wzajemnej komunikacji oraz integracja środowisk wolnościowych. Międzymiastówka stawiała sobie za cel „pozbawienie państwa sensu jego istnienia” poprzez „dążenie do eliminacji hierarchicznych struktur, dominacji i wyzysku” oraz stworzenie stanu, w którym „,społeczeństwo będzie się samo organizować w wolne wspólnoty i zrzeszenia"15. Cele i formy aktywności anarchistów i młodzieży alternatywnej stanowiły jedną z przyczyn zainteresowania się tym ruchem przez Służbę Bezpieczeństwa ${ }^{16}$.

\section{Struktury organizacyjne i główne ośrodki anarchizmu w Polsce w latach dziewięćdziesiątych XX w. i od 2000 r.}

W 1989 r. na zjeździe anarchistów w Dobrzeniu Wielkim Międzymiastówka przekształciła się w Federację Międzymiastówki Anarchistycznej. W tym samym roku zmieniła ona nazwę, przeistaczając się w Federację Anarchistyczna (FA). Odeszły z niej jednak osoby związane z formacja artystyczna Totart. Natomiast anarchiści ze Śląska rozpoczęli działalność jako Grupa

${ }^{13}$ Pomarańczowa Alternatywa, http://www.pomaranczowa-alternatywa.pl/tekst,pomaranczowaalternatywa,232.html (dostęp: 22 I 2020). Zob. też: W. Fydrych, Żywoty mężów pomarańczowych, Wrocław 2001; R. Zybrant, Wrocławskie organizacje opozycyjno-kontrkulturowe $z$ lat 80. XX wieku i ich wptyw na powstanie Pomarańczowej Alternatywy, w: 80s Again! Monografia poświęcona latom 80. XX wieku, red. A. Jabłońska, M. Koryciński, Warszawa 2017, s. 5-21.

14 J.P. Waluszko, op. cit., s. 7.

${ }^{15}$ Deklaracja MA, „Rebeliant Poranny” [b.d.w.], nr 1, s. 2.

${ }^{16}$ Zob. A. Łaniewski, „Dażność do opanowania ruchu”. Anarchiści lat 80. XX w. w świetle dokumentów i archiwów IPN, w: Studia z dziejów polskiego anarchizmu..., s. 248-262; Wszyscy proletariusze badźcie piękni! Pomarańczowa Alternatywa $w$ dokumentach aparatu represji PRL (1987-1989), wstęp, wybór, oprac. J. Dardzińska, K. Dolata, Wrocław 2011. 
An Arche. Opuściła ona FA w 1998 r. Jedną z przyczyn były różnice ideowe pomiędzy anarchistami ${ }^{17}$.

Po okresie gwałtownego rozwoju ruchu anarchistycznego w ostatniej dekadzie XX w., nastapił czas jego krystalizacji jakościowej i stabilizacji ilościowej po 2000 r. W 2002 r. Federacja liczyła 24 sekcje. Działały one w takich miastach, jak: Torun, Wrocław, Ostrowiec, Słupsk, Warszawa, Gdańsk (Trójmiasto), Poznań, Kraków, Łódź, Białystok, Sochaczew, Koszalin, Kielce, Zielona Góra, Inowrocław, Biała Podlaska, Rzeszów, Żyrardów, Częstochowa, Lubaczów, Krosno, Szczecin, Lublin, Ciechanowiec ${ }^{18}$. W 2006 r. sekcje FA prowadziły działalność w Warszawie i oddzielnie na warszawskiej Pradze, Toruniu, Wrocławiu, Słupsku, Poznaniu, Krakowie, Łodzi, Białymstoku, Zielonej Górze, Inowrocławiu, Białej Podlaskiej, Rzeszowie, Częstochowie, Szczecinie, Lublinie, Opolu, Ciechanowie, Przasnyszu, Kędzierzynie-Koźlu, Gorzowie Wielkopolskim, Żyrardowie, Łasinie, Trójmieście. Działała również nowa sekcja na Śląsku. Łącznie w tym roku istniało 25 sekcji ${ }^{19}$. W 2008 r. FA tworzyły m.in. grupy z Warszawy, warszawskiej Pragi, Ślaska, Torunia, Słupska, Trójmiasta, Poznania, Piły, Krakowa, Łodzi, Zielonej Góry, Inowrocławia, Częstochowy, Szczecina, Lublina, Opola, Ciechanowa, Kędzierzyna-Koźla, Gorzowa Wielkopolskiego, Żyrardowa, Łasina, Piły oraz Dublina w Irlandiii ${ }^{20}$. W 2020 r. FA działała w 16 regionach: w Bydgoszczy, Częstochowie, Gnieźnie, Krakowie, Koninie, Lesznie, Lublinie, Łodzi, Nowym Saczu, Ostrowie, Poznaniu, Rzeszowie, Szczecinie, Warszawie, Wrocławiu, na Śląsku ${ }^{21}$. Koniec drugiej dekady XXI stulecia to spadek liczby sekcji FA.

Podczas 30 lat istnienia FA miała dwie sekcje zagraniczne: efemeryczna $\mathrm{w}$ niemieckim Werl ${ }^{22} \mathrm{w}$ latach dziewięćdziesiątych oraz wcześniej wymieniona, w irlandzkim Dublinie. Niezmiennie w analizowanym okresie działały sekcje w Poznaniu, Warszawie, Krakowie, Gdańsku, Łodzi i Wrocławiu. Poza nimi funkcjonowanie ruchu cechowała wysoka płynność. Działalność sekcji koordynowana była przez nieregularne zjazdy, których do 2010 r. odbyło się 37 . Ten rok okazał się przełomowy dla FA, gdyż podczas zjazdu przyjęta została nowa „Płaszczyzna ideowa”, która zastapiła określającą ideowe oblicze Federacji „Płaszczyznę większościową, opracowaną w 1989 r. ${ }^{23}$

Liczba uczestników ruchu anarchistycznego zmieniała się. Sekcje tworzone były przez grupy kilku lub kilkunastoosobowe, rzadziej kilkudziesięcioosobowe,

${ }^{17}$ P. Malendowicz, op. cit., s. 29; J.P. Waluszko, op. cit.

${ }_{18}$ Federacja Anarchistyczna, www.fa.most.org.pl/fa (dostęp: 17 IX 2002).

${ }_{19}$ Federacja Anarchistyczna, http://fa.most.org.pl/?go=sekcje (dostęp: 20 XII 2006).

${ }^{20}$ Federacja Anarchistyczna, http://fa.most.org.pl/?go=adress (dostęp: 25 XI 2008).

${ }^{21}$ Federacja Anarchistyczna, http://federacja-anarchistyczna.pl/ (dostęp: 22 I 2020).

${ }_{22}$ Sekcja Polonijna F.A. w Niemczech!, „Biuletyn Informacyjny Federacji Anarchistycznej” [b.d.w.], nr 4, s. 2.

${ }^{23}$ 37. Zjazd Federacji Anarchistycznej w Poznaniu, 10 II 2010, https://www.rozbrat.org/ informacje/ruch/640-37-zjazd-federacji-anarchistycznej-w-poznaniu (dostęp: 22 I 2020). 
tylko w przypadku grup z Gdańska w latach dziewięćdziesiątych oraz Poznania w tym czasie i po 2000 r. liczebność sekcji była wyższa. Należy dodać, że określenie dokładnej liczby anarchistów w poszczególnych miastach Polski nie jest możliwe właśnie $\mathrm{z}$ uwagi na wspomnianą płynność ruchu, zmienność czasową i efemeryczność sekcji. Ponadto anarchizm cechowała stopniowalność uczestnictwa w ruchu. Jego jądro stanowił pierwszy krag anarchistów - osób zaangażowanych w ruch, publicystów, organizatorów wystapień publicznych i liderów wyznaczających kierunki działalności ruchu. W kolejnych kręgach znajdowali się uczestnicy bierni bądź okresowo aktywni, a następnie jego sympatycy, w tym wspierajacy publiczne wystapienia FA i innych organizacji, a także czytelnicy prasy anarchistycznej.

Poza FA na poziomie krajowym działały inne organizacje anarchistyczne. Wśród nich wymienić należy Ogólnopolski Związek Zawodowy Inicjatywa Pracownicza, który jako nieformalna grupa powstał w 2001 r., a jako związek zawodowy został zarejestrowany w $2004 \mathrm{r} .{ }^{24} \mathrm{Na}$ forum krajowym od $2007 \mathrm{r}$. działał także Związek Syndykalistów Polski, który stanowił sekcję Międzynarodowego Stowarzyszenia Pracowników (The International Workers Asso-

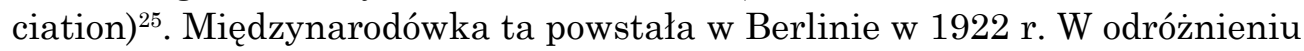
od Związku Syndykalistów Polski FA nie była członkiem międzynarodowych struktur ruchu anarchistycznego, w tym przede wszystkim Międzynarodówki Federacji Anarchistycznych (The International of Anarchist Federations), która powstała w 1968 r. w miejscowości Carrara we Włoszech ${ }^{26}$.

Główna aktywność ruchu anarchistycznego w Polsce miała jednak charakter lokalny. Poza sekcjami FA istniały setki nielicznych i najczęściej efemerycznych grup angażujących się w działalność publicystyczna, akcje społeczne i inicjatywy skierowane przeciwko innym ruchom politycznym, w tym przede wszystkim ruchowi neofaszystowskiemu. Istotną formą anarchistycznej aktywności było tworzenie wspólnot autonomicznych, tzw. squatów. Squatowanie polegało na zajmowaniu opuszczonych miejsc lub budynków bez pozwolenia ich właścicieli $^{27}$. Wspólnoty takie powstały w kilku miejscowościach, a największy squat w Polsce został utworzony w 1994 r. w Poznaniu. Mieszkańcy i goście squatu Rozbrat angażowali się w liczne akcje społeczne, w tym przede wszystkim w działalność antyeksmisyjna, antymilitarna, kulturowa, artystyczna, ekologiczna, edukacyjną oraz na rzecz imigrantów i propagowania idei libertarnych ${ }^{28}$.

\footnotetext{
${ }^{24}$ Inicjatywa Pracownicza 2001-2011 - kalendarium wydarzen, „Inicjatywa Pracownicza” 2011, nr 31, s. 12.

${ }^{25}$ International Workers Association, 7 VII 2012, https://iwa-ait.org/content/addresses (dostęp: 22 I 2020).

${ }^{26}$ International of Anarchist Federations, http://i-f-a.org/ (dostęp: 22 I 2020); „Biuletyn Informacyjny Federacji Anarchistycznej” 1997, nr 22 (11), s. 2-4; Documentos de la Internacional de Federaciones Anarquistas, Carrara 2001.

${ }_{27}$ An Introduction to Squatting, „Mesho” 2008, s. 2.

${ }^{28}$ Radykalny Poznań. Rozbrat.org, http://www.rozbrat.org/ (dostęp: 22 I 2020).
} 
Marginesem aktywności ruchu anarchistycznego w Polsce była działalność mająca znamiona terroryzmu. W 1991 r., m.in. w Gdańsku i Grudziądzu, działał Ludowy Front Wyzwolenia. W tym okresie grupa przeprowadziła zamachy na ambasadę Izraela, pomieszczenia LOT w Gdańsku, konsulat radziecki w Gdańsku i obrzuciła butelkami z benzyną Wojskową Komendę Uzupełnień w Grudziądzu. Jej członkowie zostali ujęci przez policję i Urząd Ochrony Państwa ${ }^{29}$. Natomiast w 2016 r. anarchiści niezrzeszeni w Federacji planowali zamach na jeden z komisariatów w Warszawie. Zostali również ujęci przez policję ${ }^{30}$.

Wśród innych lokalnych struktur działajacych w latach dziewięćdziesiatych XX w. i w kolejnej dekadzie wymienić należy m.in. takie jak: Lubelska Autonomiczna Grupa Anarchistów, De Doxa z Wrocławia, Zielonogórska Grupa Anarchistyczna, Bielska Bojówka Anarchistyczna, Grupa An Arche z Katowic, Autonomiczna Grupa Aktywności z Kielc, Grupy Antypaństwowe z Łukowa i Kielc, Grupa Aktywności Pińczowskiej, artystyczna Komuna Otwock, anarchofeministyczne Wiedźma z Siedlec i Koedukacyjna Unia Rewolucyjno-Wyzwoleńczo-Anarchistyczna z Warszawy ${ }^{31}$.

\section{Prasa anarchistyczna}

Poza strukturami organizacyjnymi przejawem aktywności ruchu anarchistycznego była działalność wydawnicza. W analizowanym okresie prace wydawnicze ruchu objęły prasę i pozycje zwarte, głównie o charakterze broszurowym. Szczególna rolę w systemie obiegu informacji i komunikowania ruchu anarchistycznego pełniła prasa. Poza funkcjami informacyjnymi stanowiła ona forum dyskusyjne i środek kształtowania opinii anarchistów oraz umożliwiała wzajemne komunikowanie.

Cechą prasy ostatnich dwóch dekad XX w. była prostota wydawnicza. Niektóre tytuły nie odbiegały sposobem druku i jakością wydawniczą od prasy anarchistycznej sprzed II wojny światowej, np. wydawanego przez AFP „Głosu Anarchisty". Prasa anarchistyczna była zwykle powieleniem przy użyciu ksero stron pisanych na maszynie $\mathrm{z}$ wklejonymi ilustracjami. Już jednak w ostatnim dziesięcioleciu XX w. forma wydawnicza prasy ewoluowała, a coraz większa liczba tytułów stopniowo ulegała profesjonalizacji poligraficznej. Podobnie jak przy liczebności struktur anarchistycznych, tak i w przypadku prasy tego ruchu nie są znane dokładne nakłady czasopism. Nieprofesjonalne tytuły powielano w nakładach od kilku i kilkudziesięciu egzemplarzy, ale tytuły profesjonalne,

\footnotetext{
${ }^{29}$ M. Rzeszut, Grudziadzcy „terroryści” przypomnieli o sobie, „Gazeta Pomorska” 1991, nr 239, s. 1; Ja anarchista. Wywiad z Piotrem Ratyńskim, „Gazeta Pomorska” 1992, nr 86, s. 5.

${ }^{30}$ Anarchiści planowali zamach na komisariat $w$ Warszawie. Policja złapała ich na goracym uczynku, $25 \mathrm{~V}$ 2016, https://www.newsweek.pl/polska/anarchisci-planowali-zamach-nakomisariat/9m9c3pn (dostęp: 22 I 2020).

${ }^{31}$ P. Malendowicz, op. cit., s. 30-67.
} 
o wysokim poziomie edytorskim, zwielokrotniane w drukarniach, wydawano w nakładach przekraczajacych kilkaset sztuk, niekiedy w tysiącach egzemplarzy, choć niezbyt często. Różne były objętości czasopism: od 1 strony do ponad 300. Do redakcji czasopisma należała zwykle jedna osoba, rzadziej kilka. Redakcje stanowiły substytut struktur organizacyjnych. Wokół nich gromadzili się sympatycy anarchizmu. Także tematyka czasopism była zróżnicowana - od prasy typowej dla subkultur młodzieżowych, ubogiej w treści, ale bogatej $\mathrm{w}$ grafikę, do profesjonalnych, podejmujacych istotne tematy analitycznych publikacji. Pod koniec pierwszej dekady XXI w. działalność wydawnicza anarchistów nie odznaczała się już jednak taką dynamika, jak w poprzedniej dekadzie. Przyczyną było mniejsze zainteresowanie anarchizmem ludzi młodych, a także przenoszenie aktywności publikacyjnej do Internetu.

Tytuły anarchistycznych periodyków miały charakter ideologiczny, informacyjny, sprofilowany, subkulturowy bądź prowokacyjny. Wśród głównych wydawnictw wymienić należy takie jak: „Mać Pariadka” (wydawana w latach 1990-2005 z przerwami, ze zmiennie formułowanymi podtytułami), „Przegląd Anarchistyczny” (publikowany od 2003 r., początkowo jako „Biuletyn Poznańskiej Biblioteki Anarchistycznej”), „Inny Świat” (wydawany od 1993 r.). Inne tytuły wydawane na przełomie lat osiemdziesiątych i dziewięćdziesiątych XX w. to m.in.: „Homek” (od 1983 r.), „A Cappella”, „Fraternité”, „Rewolta”, „Anarcholl”, „Psychopata”, „Rebeliant Poranny”, a następnie od ostatniej dekady XX w. po kolejne stulecie - np.: „A-tak”, „Gazeta An Arche”, „Antypolityka”, „Inicjatywa Pracownicza”, „Ulica”, „Czarna Gwiazda”, „Czarny Blok”, „Czarny Sztandar”, „Wybór Polityczny”, „Lokomotywa Bez Nóg”, „Parada Krytyczna”, „Monada”, „Podaj Dalej”, „Robol”, „Zmowa Robotnicza”, „Syndykalista”, „Szerszuń, „Tej”, „Uczeń i Uczennica”, „Buntownik”, „Biuletyn Informacyjny Anarchistycznego Czarnego Krzyża”, „Biuletyn Informacyjny Federacji Anarchistycznej”. Tylko nieliczne oznaczano ISSN i można je było nabyć w salonach prasowych. Inne kolportowano w ramach alternatywnego obiegu prasy i wydawnictw zwartych.

\section{Udział anarchistów w działalności akcyjnej}

Poza strukturami organizacyjnymi i redakcjami czasopism anarchiści inicjowali inne przedsięwzięcia nietemporalne. Jednym z nich był udział w tworzeniu i organizowaniu w kraju Pacyfistycznych Komend Uzupełnień (PKU). Funkcjonowały one w okresie powszechnego i obowiązkowego poboru do wojska. Ich działacze protestowali przeciwko przymusowi poborowemu młodych ludzi i opowiadali się za jego likwidacją. Pomagali też osobom chcącym uniknąć służby wojskowej w uzyskaniu możliwości odbycia służby zastępczej. Na przełomie wieków istniało w Polsce kilkadziesiąt punktów $\mathrm{PKU}^{32}$.

${ }^{32}$ Pacyfistyczna Komenda Uzupetnien. Wywiad $z$ R. Barankiem, „Młyn. Nieokrzesany dwutygodnik młodzieżowy" [b.d.w.], s. 1. 
Inną inicjatywą była aktywność w ramach Anarchistycznego Czarnego Krzyża (ACK, The Anarchist Black Cross). To międzynarodowa sieć grup anarchistycznych i pojedynczych osób pomagających więźniom i osobom represjonowanym za antyautorytarne przekonania i działalność społeczno-polityczna. ACK organizował pomoc prawną oraz materialna i prowadził kampanie na rzecz uwolnienia więźniów i zaprzestania represji wobec nich. Działania tego rodzaju, w czasie których używana była nazwa ACK, prowadzono w Polsce od 1994 r. W latach 1996-2003 istniała ogólnopolska sieć ACK. Składała się ona z autonomicznych, lokalnych grup i osób. W 1996 r. tworzyły ją grupy z Warszawy, Opola, Poznania, Zielonej Góry, Dąbrowy Górniczej, Słupska, Bogatyni, Trójmiasta i Krakowa, a w kolejnych latach grupy z Wrocławia, Wodzisławia, Ciechanowca, Koszalina, Radomia, Torunia, Bydgoszczy, Gliwic, Płocka, Krosna, Łodzi i Lublina. W 2003 r. na liście ośrodków ACK widniały adresy grup z Poznania, Łodzi, Trójmiasta, Wrocławia i Warszawy. Po 2003 r. ACK jako sieć przestała istnieć z uwagi na nikłe zainteresowanie jej działalnościa. Od tego czasu na forum lokalnym działały tylko nieliczne grupy $\mathrm{ACK}^{33}$.

Anarchiści uczestniczyli także w kampanii „Żaden człowiek nie jest nielegalny" (No One Is Illegal), która rozpoczęła się w 1997 r. w Niemczech. Celem kampanii była pomoc imigrantom. Jej uczestnicy sprzeciwiali się deportacjom i propagowali ideę likwidacji granic państwowych. W Polsce forma kampanii były demonstracje, działalność wydawnicza i organizacja obozów antygranicznych. Jeden z nich w 1999 r. odbył się w niemieckim Zittau (Żytawa) ${ }^{34}$.

Inną forma anarchistycznej aktywności była kampania „Jedzenie zamiast bomb" (Food Not Bombs). Polscy anarchiści prowadzili ja od lat 1998-1999. Miała ona charakter antymilitarny. W jej zakresie organizowali zbiórki pieniędzy i żywności dla najuboższych ${ }^{35}$. Później jej przejawem było przygotowywanie oraz wydawanie ciepłych i darmowych posiłków wegańskich osobom potrzebujacym. Akcja stanowiła wyraz sprzeciwu wobec wojen i zbrojeń, w kontraście z innymi potrzebami społecznymi, przede wszystkim potrzebami ludzi żyjących na marginesie społeczeństwa ${ }^{36}$.

To wybrane przykłady aktywności anarchistów. Poza nimi angażowali się oni w inne akcje antymilitarne, pacyfistyczne, a także ekologiczne, antyfaszystowskie, przeciwko eksmisjom, na rzecz rozwoju kultury alternatywnej, antyglobalizacyjne i w kontekście bieżących wydarzeń politycznych na poziomie lokalnym, krajowym i międzynarodowym.

\footnotetext{
${ }^{33}$ Anarchistyczny Czarny Krzyż. Serwis informacyjny, http://www.ack.most.org.pl/ (dostęp: 23 I 2020).

${ }^{34}$ Żaden człowiek nie jest nielegalny, „Wzbronione” 1999, nr 3, s. 3.

${ }^{35}$ Food Not Bombs, „Inny Świat” [b.d.w.], s. 6-7.

${ }^{36}$ Jedzenie zamiast bomb, http://foodnotbombs.pl/ (dostęp: 23 I 2020).
} 


\section{Nurty dominujące w polskim anarchizmie na przełomie XX i XXI w.}

Jako kierunek myśli politycznej anarchizm nie jest jednolity. W polskim ruchu anarchistycznym $\mathrm{w}$ analizowanym okresie dominowały jego nurty komunistyczny i syndykalistyczny. Anarchokomunizm to w lapidarnym ujęciu połączenie idei wspólnotowej przyszłości z wolnościowymi ideami, które legły u podstaw anarchizmu. Ten nurt, odwołujacy się do myśli Piotra Kropotkina i Errica Malatesty, niekiedy do kolektywizmu Michaiła Bakunina, a na gruncie polskim do myśli Wróblewskiego, reprezentowany był przez większość grup i sekcji FA. Anarchosyndykalizm to natomiast zunifikowanie idei wolności z formami walki i postulatem organizacji przyszłych stosunków społecznych w oparciu o związki zawodowe. Właściwy był zatem takim związkom zawodowym, jak Inicjatywa Pracownicza i Związek Syndykalistów Polski.

Poza tym w polskim ruchu anarchistycznym działały grupy anarchofeministyczne, np. Wiedźma. Anarchofeminizm to kwestionowanie hierarchii płci, a następnie upatrywanie możliwości osiagnięcia wolnościowego społeczeństwa za sprawą likwidacji męskiej dominacji. Przeciwko autorytaryzmowi kultury opowiadali się anarchiści sytuacjoniści, skupieni głównie wokół redakcji czasopism „Rewolta”, „Monada” i „Parada Krytyczna”. Niemal do końca lat dziewięćdziesiątych ruch anarchistyczny w Polsce współtworzyli śląscy libertarianie z Grupy An Arche. Dominującymi wartościami w libertarianizmie były wolność i własność w ujęciu indywidualistycznym. Taka koncepcja wolności indywidualnej zdecydowała o odejściu tej grupy z FA. W ruchu działali też tzw. anarchiści zieloni, czyli reprezentujący ekologiczne nurty anarchizmu. Widzieli oni możliwości i szanse przetrwania życia na Ziemi w realizacji postulatów radykalnie ekologicznych i organizacji życia społecznego opartego na idei zgodności z natura i równości organizmów żywych. Anarchiści alternatywiści poszukiwali możliwości realizacji ideałów anarchistycznych w tworzeniu wspólnot squaterskich. W końcu analizowanego okresu umiarkowane znaczenie zyskał anarchizm insurekcyjny, który postulował organizowanie manifestacji, zamieszek, a także powstań przeciwko państwu. Mniejszościa w polskim ruchu anarchistycznym byli niezorganizowani anarchopacyfiści. Próbę osiagnięcia kompromisu w ideowych sporach pomiędzy anarchistami stanowił natomiast anarchizm bezprzymiotnikowy.

\section{Stanowisko anarchistów wobec przemian politycznych w Polsce i głównych kierunków polskiej polityki}

Ruch anarchistyczny w Polsce odradzał się i kształtował w okresie przemian politycznych lat osiemdziesiątych i dziewięćdziesiątych XX w., a także realizacji głównych wyzwań politycznych i gospodarczych w kolejnej dekadzie. 
To determinowało myśl polityczną tego ruchu, w tym programy grup anarchistycznych i publicystykę czasopism o tym profilu ideowym.

Cechą anarchizmu jest bezkompromisowy sprzeciw wobec władzy i instytucji państwa, co determinuje maksymalistyczna interpretacja idei wolności. Dlatego anarchiści podjęli krytykę państwa i jego władzy już w okresie odradzania się ruchu w latach osiemdziesiątych. W następnych latach publicystyka libertarna nadal żywo interesowała się wydarzeniami tamtego okresu. Przykładowo po wielu latach od wprowadzenia stanu wojennego na łamach czasopisma „A-tak” ukazał się artykuł, którego autorzy pisali: „Mija 34 lata od momentu wygłoszenia przemówienia, w którym generał Jaruzelski, odwołując się do troski o bezpieczeństwo ludowego państwa, uzasadniał wprowadzenie stanu wojennego. Na ulicach pojawiły się czołgi, tysiące osób znalazło się $\mathrm{w}$ obozach internowania, wzmożono cenzurę prewencyjną... Ludzie zostali przybici totalitarna pięścia państwa"37.

Jednakże dla anarchistów „Każdy ustrój państwowy i każda partyjność, nieważne czy bliższa «demokracji», czy dyktaturze, ma w sobie pierwiastek autorytatywny. Jest nim zasada władzy, która zawsze, choć z różnym nasileniem, opiera się na nierówności, sprowadza niesprawiedliwość i niewolę, $\mathrm{z}$ różną dynamika, jednak w sposób nieprzerwany, zmierza w kierunku totalności, wbrew rzeczywistej naturze i potrzebom ludzi" ${ }^{38}$.

Takie stanowisko było przesłanką krytyki nie tylko władzy państwowej i partyjnej w Polsce Ludowej, ale także w okresie transformacji w 1989 r. W tym czasie anarchiści redagujący czasopismo „Homek” na bieżąco analizowali wybory z czerwca tego roku. Według redakcji czasopisma 4 VI 1989 r. do wyborów nie przystapiło ok. 10 mln osób, a „drugie tyle - wbrew apelom Wałęsy - skreśliło komunistów z listy krajowej”. Miało to świadczyć o niechęci społeczeństwa do władzy i o tym, że mit Solidarności był ciagle żywy, gdyż ugodowa polityka kierownictwa związku w stosunku do komunistów nie cieszyła się poparciem społecznym ${ }^{39}$. We wrześniu tego roku Piotr Rymarczyk w artykule pt. Dzieje pewnej zdrady, opublikowanym w czasopiśmie „Rewolta”, pisał, że społeczeństwo polskie wiąże nadzieje z rządem Tadeusza Mazowieckiego, dotyczace przede wszystkim jego wysiłków na rzecz poprawy warunków życia. Jednakże, jak stwierdził, ten rząd był „praktyczna realizacja PZPR-owskiej idei wielkiej koalicji Solidarności z organizacjami reprezentującymi reżim komunistyczny". Miało to świadczyć o zaawansowaniu procesu integracji solidarnościowego establishmentu z systemem władzy, co stanowiło efekt polityki ugody. Według autora artykułu

\footnotetext{
${ }^{37}$ Stan wojenny „wczoraj” $i$ dziś..., „A-tak” 2016, nr 2, s. 4.

${ }^{38}$ Ibidem.

${ }^{39}$ Redakcja, 4ego czerwca..., „Homek” 1989, nr 38, s. 1.
} 
Komuniści dając związkowemu establishmentowi możliwość legalnego działania i współudział we władzy słusznie przewidywali, że obdarowani bojąc się utracić to, co już maja, będą powstrzymywać wszystkie bardziej radykalne wystapienia społeczne. Obecne losy członków tego establishmentu to żywa ilustracja tezy, iż „władza to trucizna”. Niedawni bohaterowie stopniowo zmieniają się w „solidnych polityków” zainteresowanych głównie kariera, forsą i świętym spokojem. Diametralnie zmieniła się też ideologia związku. Idea samoorganizującego się społeczeństwa zastapiona została przez koncepcję „mądrego kierownictwa” [...]. Politykę oddolnych nacisków i akcji bezpośredniej zastapiono polityką tajnych rokowań w zaciszu gabinetów. Wreszcie idea wprowadzenia gospodarki samorządowej - w której obecne sa wartościowe elementy ekonomiki kapitalistycznej (wolny rynek), a nieobecne negatywne (niesprawiedliwości majątkowe, alienacja) - zamieniona została na program reprywatyzacji ${ }^{40}$.

Oceny wydarzeń 1989 r. w Polsce, formułowane na bieżąco w tym właśnie roku, były tożsame z treścią publicystyki anarchistycznej w kolejnych latach. W 2000 r. w czasopiśmie „Mać Pariadka” opublikowany został artykuł publicystyczny, którego autor sugerował, że elity polskiej opozycji politycznej pod koniec lat osiemdziesiątych były zdominowane przez warszawskich „doradców" Solidarności, co doprowadziło do tego, że porzuciły ideały Sierpnia '80 i komitetów obywatelskich. Okragły Stół został zdominowany przez osoby desygnowane przez Lecha Wałęsę, a kampania przed wyborami prezydenckimi ujawniła partykularne interesy osób z władz związku ${ }^{41}$. Taka interpretacja procesów politycznych z 1989 r. była bliska myśli politycznej Machajskiego, która cechowała wrogość wobec inteligencji ${ }^{42}$. W interpretacji anarchistów „doradcy”, którzy przeniknęli do kierownictwa Solidarności, to właśnie inteligencja, która chciała wyzyskać związek do partykularnych celów.

Prasa alternatywna kontestowała procesy polityczne z $1989 \mathrm{r}$. nie tylko w analitycznych artykułach i krytycznych ocenach wyraźnie sprofilowanych ideologicznie, ale także $\mathrm{w}$ formie satyry. W jednym $\mathrm{z}$ czasopism tego okresu opublikowany został persyflaż pt. Komiks polityczno-kanibalistyczny czyli nasi $w R P A$. Opiewał on wizytę Wojciecha Jaruzelskiego i Tadeusza Mazowieckiego w Afryce. Tam politycy mieli zostać napadnięci przez dwa plemiona miejscowych ludożerców. Na pytanie przedstawiciela jednego z nich o podział łupów reprezentant drugiego plemienia odpowiedział: „wasz prezydent, nasz premier" ${ }^{43}$.

Na przełomie XX i XXI w. publicystykę anarchistyczna zdominowały sprawy organizacyjne ruchu i zagadnienia związane z kształtowaniem jego

${ }^{40}$ P. Rymarczyk, Dzieje pewnej zdrady, „Rewolta” 1989, nr 2, s. 2.

${ }^{41}$ Zob. M. Muskat, Solidarność 1980-2000. Sukces w oczach świata, klęska w oczach Polaków, „Mać Pariadka” 2000, nr 4, s. 65-69.

${ }_{42}$ Zob. M.J. Zacharias, Inteligencja, socjalizm i rewolucja w myśli politycznej Jana Wactawa Machajskiego (1866-1926), „Dzieje Najnowsze” 2019, nr 3, s. 69-104.

${ }^{43}$ Komiks polityczno-kanibalistyczny czyli nasi w RPA, „Przegięcie Pały” [b.d.w.], nr 8, s. 1. 
oblicza ideowego, jak również analizy bieżących wydarzeń politycznych, kwestionowanie Paktu Północnoatlantyckiego, negacja kapitalizmu, krytyka demokracji i procesu integracji europejskiej.

Szczególny przedmiot zainteresowania ruchu stanowiła problematyka demokracji i przyszłości Europy. W ocenie demokracji parlamentarnej anarchiści podkreślali, że daje ona „wolność tylko takiej grupie, która tworzy większość i ma możliwości wyrażania oraz narzucania swojej woli poprzez parlament i środki masowego przekazu" ${ }^{4}$. Zwracali ponadto uwagę na alienacje elit politycznych i ekonomicznych ze społeczeństwa, pauperyzację i podziały społeczne. Anarchiści byli również przeciwni integracji europejskiej, w tym wstapieniu Polski do UE. Opinie w tej sprawie motywowali także maksymalistyczna interpretacją idei wolności. Przed wstapieniem Polski do UE opublikowali stanowisko, zgodnie z którym

\begin{abstract}
Planowane [...] wejście Polski do struktur UE spowoduje zdublowanie instytucji państwowych, a co za tym idzie zwiększenie zakresu i rozmiaru państwa oraz jego ingerencji w życie obywateli. Spowoduje to także powstanie megapaństwa z megapolicja [...] i tajnymi, dobrze opłacanymi służbami bezpieczeństwa, skutecznymi $\mathrm{w}$ walce $\mathrm{z}$ wszelkimi przejawami niezależności [...]. Z drugiej strony [...] to nie szczytne hasła współpracy między narodami, wymiany kulturalnej i naukowej były podstawa zawiązania Unii, lecz zwykłe przyziemne interesy finansowe wielkich multikorporacji, które chciały uzyskać swobodę przepływu kapitału, towarów i możliwość opanowywania coraz to nowych rynków zbytu na swoje produkty ${ }^{45}$.
\end{abstract}

\title{
Zakończenie
}

Ruch anarchistyczny w Polsce odradzał się i kształtował od lat osiemdziesiatych XX w. Apogeum jego aktywności nastapiło pod koniec ostatniej dekady tego stulecia. Po 2010 r. nastapił spadek aktywności anarchistów w Polsce, co można tłumaczyć inercją polityczną młodych ludzi, a jednocześnie wzrostem ich zainteresowania ruchami nacjonalistycznymi. Anarchizm w Polsce odradzał się i kształtował w oparciu o maksymalistycznie interpretowana ideę wolności, o czym świadczy negacja państwa, czyniona niezależnie od jego formy ustrojowej, a także kwestionowanie każdej formy władzy, UE, NATO, jak również ukrytych struktur władzy globalizacyjnej. Jako ruch anarchizm pozostawał na marginesie form aktywności politycznej w Polsce. Liczebność, radykalizm ideowy, rzadziej ekstremizm działania, efemeryczność i płynność przejawów jego aktywności nie sprzyjały krystalizacji ruchu anarchistycznego w dłuższej perspektywie czasowej.

\footnotetext{
${ }^{44}$ Salwa, Demokracja parlamentarna, „Rewolta” 1989, nr 3, s. 8.

${ }^{45}$ Stanowisko anarchistów wobec Unii Europejskiej, http://www.innyswiat.most.org.pl/w/ ue.htm (dostęp: 23 I 2020).
} 


\section{Streszczenie}

Przedmiotem artykułu jest historia ruchu anarchistycznego w Polsce od lat osiemdziesiątych XX w. Ruch anarchistyczny na ziemiach polskich istniał przed II wojna światowa. Jednakże w okresie rządów komunistycznych jego działalność została zakończona. Ruch anarchistyczny odrodził się na początku lat osiemdziesiątych XX w. Pierwszą grupą anarchistyczną w Polsce po II wojnie światowej był Ruch Społeczeństwa Alternatywnego, który powstał w 1983 r. W 1989 r. ukształtowała się Federacja Anarchistyczna. Istniały także inne grupy anarchistyczne oraz anarchosyndykalistyczne związki zawodowe. Anarchiści wydawali również czasopisma. Najważniejsze z nich to: „Mać Pariadka”, „Inny Świat” i „Przegląd Anarchistyczny”. Anarchiści w analizowanym okresie byli aktywni także w innych akcjach, np. „Jedzenie zamiast bomb”, „Żaden człowiek nie jest nielegalny”. Najważniejsze nurty myśli anarchistycznej to anarchokomunizm, anarchosyndykalizm, anarchofeminizm, anarchizm zielony, anarchizm insurekcyjny, sytuacjonizm, libertarianizm, anarchopacyfizm, anarchizm bezprzymiotnikowy. W polskiej myśli anarchistycznej dominowały anarchokomunizm i anarchosyndykalizm. Anarchiści zanegowali przemiany polityczne w Polsce w 1989 r. Byli przeciwnikami Unii Europejskiej i NATO. Krytykowali władzę i państwo. Przyczynę tego stanowiła maksymalistyczna interpretacja idei wolności.

\section{Rebirth and Formation of the Anarchist Movement in Poland since the 1980s}

The subject of this article is the history of the anarchist movement in Poland since the 1980s. The anarchist movement existed in Poland before World War II. However, during the communist rule, its activities ceased. The anarchist movement was revived at the beginning of the 1980s. The first anarchist group formed in Poland after World War II was the Alternative Society Movement, established in 1983. In 1989, the Anarchist Federation was founded. There were other anarchist groups and anarcho-syndicalist trade unions. Anarchists published periodicals; the most important of them were: Mać Pariadka, Inny Świat (Another World), and Przeglad Anarchistyczny (Anarchist Review). Anarchists in the analysed period also participated in other actions, such as Food Not Bombs, or No One Is Illegal. The most relevant trends of anarchist thought are: anarcho-communism, anarcho-syndicalism, anarcho-feminism, green anarchism, insurrectionist anarchism, situationism, libertarianism, anarcho-pacifism, anarchism without adjectives. Anarcho-communism and anarcho-syndicalism dominated in the Polish anarchist thought. Anarchists criticised political transformation in Poland in 1989. They were against the European Union and NATO. They reprehended authorities and the state. The reason for it was the maximalist interpretation of the idea of freedom.

\section{Bibliografia}

80s Again! Monografia poświęcona latom 80. XX wieku, red. A. Jabłońska, M. Koryciński, Warszawa 2017.

Antonów R., Pod czarnym sztandarem. Anarchizm w Polsce po 1980 roku, Wrocław 2004. Chwedoruk R., Ruchy i myśl polityczna syndykalizmu w Polsce, Warszawa 2011.

Donaghey J., Punk and Anarchism. UK, Poland, Indonesia, Loughborough 2016.

Fydrych W., Żywoty mę̇̇ów pomarańczowych, Wrocław 2001.

Jeleń A., Dr Józef Zieliński - polski anarchista w Paryżu, w: Studia z dziejów polskiego anarchizmu, red. E. Krasucki, M. Przyborowski, R. Skrycki, Szczecin 2011, s. 174-187.

Kołodziej W., Anarchizm i anarchiści w Rosji i Królestwie Polskim, Toruń 1992. 
Kulczycki L., Anarchizm w obecnym ruchu społeczno-politycznym w Rosji, Warszawa 1907. Łaniewski A., Augustyn Wróblewski: krakowski anarchista $i$ „adwokat umartych”, „Studia z Dziejów Rosji i Europy Środkowo-Wschodniej” 2010, t. XLV.

Łaniewski A., „Dażność do opanowania ruchu”. Anarchiści lat 80. XX w. w świetle dokumentów i archiwów IPN, w: Studia z dziejów polskiego anarchizmu, red. E. Krasucki, M. Przyborowski, R. Skrycki, Szczecin 2011, s. 248-262.

Łaniewski A., Wizerunek anarchistów $i$ anarchii na łamach „Naprzodu” $i$ „Robotnika” (1892-1927), „Dzieje Najnowsze” 2014, nr 4.

Malendowicz P., Polski ruch anarchistyczny wobec wspótczesnych wyzwań politycznych, Piła 2007.

Muszyński J., Anarchizm. Rzecz o nieziszczalnej wolności, Warszawa 1982.

Potkański W., Działalność ruchów anarchistycznych w Królestwie Polskim na przełomie XIX $i$ XX stulecia, „Bezpieczeństwo. Teoria i Praktyka” 2014, nr 4.

Potkański W., Terroryzm na ustugach ugrupowań lewicowych i anarchistycznych $w$ Królestwie Polskim do 1914 roku, Warszawa 2014.

Tuchman B.W., The Proud Tower. A Portrait of the World Before the War, London 1966.

Waluszko J.P., Ruch Społeczeństwa Alternatywnego, Sopot 1992.

Wierzchoś D., Polscy anarchiści podczas rewolucji i wojny domowej w Rosji (1917-1920), w: Studia z dziejów anarchizmu (2). W dwusetlecie urodzin Michaita Bakunina, red. R. Skrycki, Szczecin 2016, s. 225-245.

Zacharias M.J., Inteligencja, socjalizm i rewolucja $w$ myśli politycznej Jana Wactawa Machajskiego (1866-1926), „Dzieje Najnowsze” 2019, nr 3.

Pawel Malendowicz - dr hab. nauk społecznych w zakresie nauk o polityce, profesor uczelni, kierownik Katedry Myśli Politycznej i Ruchów Społecznych na Wydziale Nauk o Polityce i Administracji Uniwersytetu Kazimierza Wielkiego w Bydgoszczy. Zainteresowania badawcze: anarchizm w Europie, radykalna lewica i skrajna prawica w Polsce i na świecie, koncepcje przyszłości w programach ugrupowań politycznych, Polonia w Stanach Zjednoczonych. E-m ail: p.malendowicz@ukw.edu.pl.

Pawel Malendowicz - dr hab. in social sciences in the field of political sciences, university professor, head of the Department of Political Thought and Social Movements at the Faculty of Political Science and Administration of Kazimierz Wielki University in Bydgoszcz. Research interests: anarchism in Europe, hard left and the far right in Poland and the world, concepts of the vision of future in the policy of political groups, Polish Americans in the United States. E-mail: p.malendowicz@ukw.edu.pl. 